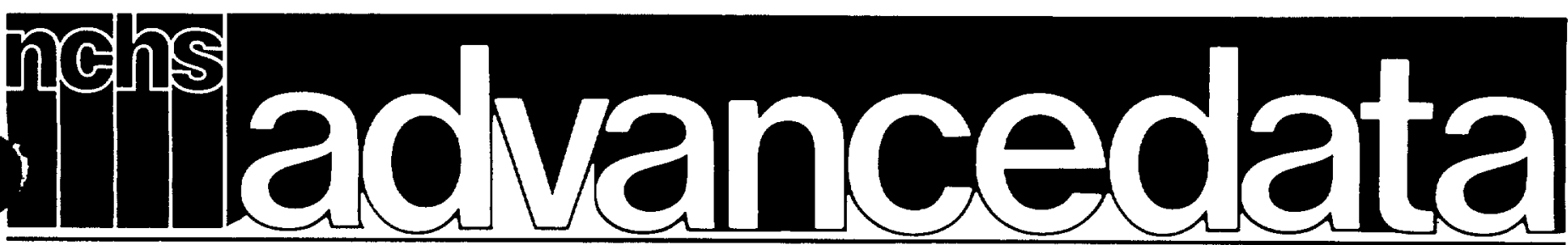

From Vital and Health Statistics of the National Center for Health Statistics

Number $135 \cdot$ May 14,1987

\title{
Use of Nursing Homes by the Elderly: Preliminary Data From the 1985 National Nursing Home Survey
}

\author{
by Esther Hing, Division of Health Care Statistics
}

\section{Introduction}

Most elderly people are not in nursing homes. Of an estimated 28.5 million Americans aged 65 years and over in the United States, only 5 percent were residents of nursing homes n any given day from August 1985 through January 1986. his finding from the 1985 National Nursing Home Survey (NNHS) is consistent with findings from previous National Nursing Home Surveys conducted in 1973-74 and 1977. ${ }^{1}$ In these surveys also it was found that about 5 percent of the elderly were residents of nursing homes.

Differences, however, exist in the use of nursing homes by age, sex, and race subgroups. In this report, these differences in use rates are examined. Differences in the health and socioeconomic characteristics of elderly nursing home residents by age, sex, and race are also discussed. The health and socioeconomic characteristics examined in this report are functional dependencies in the basic activities of daily living-bathing, dressing, using the toilet room, transferring from a bed or chair, continence, and eating; cognitive functioning (disorientation or memory impairment and senile dementia or chronic organic brain syndrome); marital status at admission; whether residents had living children; living arrangements prior to admission to the nursing home; and primary source of payment at admission. The focus of this report will be a comparison of the characteristics of the elderly who reside in nursing homes with characteristics of those who reside in the community.

The data presented in this report are from the $1985 \mathrm{Na}-$ tional Nursing Home Survey, a nationwide sample survey of nursing homes, their residents, discharges, and staff conducted by the National Center for Health Statistics. The survey, which as conducted from August 1985 through January 1986, was he third of a continuing series of nursing home surveys. The first survey was conducted from August 1973 through April
1974 , and the second was conducted from May through December 1977.

Facilities included in the 1985 NNHS were nursing and related care homes in the conterminous United States that had three or more beds set up and staffed for use by residents and that routinely provided nursing and personal care services. A facility could be free standing or could be a nursing care unit of a hospital, retirement center, or similar institution as long as the unit maintained financial and employee records separate from the parent institution. Places providing only room and board were excluded, as were places serving only persons with specific health problems (for example, mental retardation or alcoholism).

The sampling frame for the 1985 NNHS consisted of the following components:

- The 1982 National Master Facility Inventory (NMFI), ${ }^{2}$ a census of nursing and related care homes conducted by the National Center for Health Statistics.

- Homes identified in the 1982 Complement Survey of the NMFI as "missing" from the 1982 NMFI.

- Nursing homes opened for business from 1982 through June 1984.

- Hospital-based nursing homes identified in records of the Health Care Financing Administration.

The resulting frame contained 20,749 nursing homes. In this report, the terms "nursing homes" and "nursing and related care homes" are used interchangeably.

Estimates in this report are based on a sample of 4,646 elderly residents of the 1,079 nursing homes participating in the survey. A fixed sample of five or fewer residents per sample facility was selected. Residents included in the sample were those on the nursing home's roster the night before data collection began. Data were collected by interviewing knowledgeable 
nursing home staff members, who referred to the residents' medical records when necessary. Additional followup information on the sample residents was collected by telephone interview with the residents' next of kin. (A resident's guardian or friends were contacted if there was no next of kin.) Data collected from the next of kin focused on the circumstances and reasons for the resident's nursing home admission. In this report, only data obtained from the nursing home staff are presented. In later reports estimates from the next-of-kin component will be included.

Data presented in this report are preliminary and may differ slightly from estimates presented in later reports because of further data editing. Another report presenting preliminary estimates of nursing homes and utilization characteristics of homes has already been published. ${ }^{3}$

Although data on residents reported by the nursing home staff were collected in a similar manner in earlier National Nursing Home Surveys as in the 1985 survey, note should be taken of some differences. First, personal care and domiciliary care homes were excluded from the scope of the 1973-74 NNHS but included in the two later surveys. The effect of this difference, however, is small because only about 2 percent of all nursing homes in 1973 were personal care or domiciliary care homes and they housed only about 1 percent of the beds and residents. ${ }^{4}$ Second, certain variables presented in this and later reports were not available from the previous surveys. Data on some variables discussed in this report-marital status at admission, the presence of living children, ability to transfer in or out of a bed or chair, and primary source of payment at admission-were not collected in the earlier surveys. Third, race and ethnicity were collected as a single item in the 197374 and 1977 surveys but as separate items in 1985. This difference should be considered when comparing data by race from the 1985 NNHS and previous surveys.

Because data in this report are national estimates based on a sample, they are subject to sampling errors. Information on sampling variability is presented in the Technical notes.

\section{Utilization rates}

In 1985 an estimated $1,491,400$ residents lived in 19,100 nursing homes nationwide. Of these residents, $1,315,800$, or 88 percent, were 65 years of age and over. The number of elderly residents in nursing homes increased 17 percent from 1977 to 1985 . Residents aged 85 years and over comprised the largest age group ( 45 percent), followed by those aged 74-85 years ( 39 percent) and 65-74 years (16 percent). Because of the preponderance of the very old in nursing homes, those aged 85 years and over accounted for 76 percent of the increase in elderly residents from 1977 to 1985 . The proportion of elderly residents who were aged 85 years and over increased from 40 percent in 1977 to 45 percent in 1985.

Not only were nursing home residents typically very old but they also tended to be female and white. Seventy-five percent of elderly residents were female. Similarly, 93 percent of elderly residents were white. Only 6 percent were black, and less than 1 percent were other races (a category that includes Asian and Pacific Islanders, American Indians, and Alaska Natives). On the average, elderly females were older than their male counterparts ( 84 versus 81 years). Elderly white residents, who had an average age of 83 years, also tended to be slightly older thar elderly black residents ( 81 years) and other residents ( 80 years)

As measured by the percent of elderly residing in nursing homes, the patterns of nursing home utilization mirrored the distributions of residents by age, sex, and race. On any given day during the survey period, 5 percent of the population aged 65 years and over resided in nursing homes (table 1 ). The rate of nursing home use increased sharply from 1 percent of those aged 65-74 years to 22 percent of those 85 years and over. Elderly females were twice as likely as elderly males to be residents of nursing homes. Six percent of elderly females were in nursing homes, compared with 3 percent of elderly males. Although use of nursing homes increased with advancing age for both sexes, women used nursing homes at significantly higher rates than men did regardless of the age group. Greater use by women was especially true in the oldest age group. One in four women 85 years of age and over resided in nursing homes, compared with one in seven men of the same age (figure 1). This greater utilization by elderly women than men is a reflection of women's longer life expectancy. ${ }^{5}$ It is also a reflection of a greater tendency among persons without spouses and with poor health to enter nursing homes.

Elderly white persons are more likely to reside in nursing homes than black persons and those of other races are. In 1985, 5 percent of the elderly white population, compared with 4 and 2 percent of the population of black and other races, respectively resided in nursing homes. The greater likelihood of elderly whit people to reside in nursing homes was particularly true in the oldest age group. Of the population 85 years and over, 23 per-

Table 1. Number, percent distribution, and rate of nursing home residents 65 years of age and over by age, sex, and race: United States, 1985

\begin{tabular}{|c|c|c|c|}
\hline Age, sex, and race & $\begin{array}{l}\text { Number } \\
\text { of residents }\end{array}$ & $\begin{array}{c}\text { Percent } \\
\text { distribution }\end{array}$ & $\begin{array}{l}\text { Number of } \\
\text { residents per } \\
1,000 \\
\text { population } \\
65 \text { years } \\
\text { and over }\end{array}$ \\
\hline Total. . . . . . . . . & $1,315,800$ & 100.0 & 46.1 \\
\hline \multicolumn{4}{|l|}{ Age } \\
\hline $\begin{array}{l}65-74 \text { years } \ldots \ldots \ldots \\
75-84 \text { years } \ldots \ldots \ldots \\
85 \text { years and over . . }\end{array}$ & $\begin{array}{l}212,100 \\
509,000 \\
594,700\end{array}$ & $\begin{array}{l}16.1 \\
38.7 \\
45.2\end{array}$ & $\begin{array}{r}12.5 \\
57.7 \\
219.4\end{array}$ \\
\hline \multicolumn{4}{|l|}{ Sex } \\
\hline $\begin{array}{l}\text { Male............. } \\
\text { Female ... . . . . }\end{array}$ & $\begin{array}{l}334,000 \\
981.900\end{array}$ & $\begin{array}{l}25.4 \\
74.6\end{array}$ & $\begin{array}{l}29.0 \\
57.7\end{array}$ \\
\hline \multicolumn{4}{|l|}{ Race } \\
\hline $\begin{array}{l}\text { White } \ldots \ldots \ldots \ldots \ldots \\
\text { Black } \ldots \ldots \ldots \ldots \ldots \\
\text { Other } \ldots \ldots \ldots \ldots \ldots\end{array}$ & $\begin{array}{r}1,224,900 \\
82,000 \\
8,900\end{array}$ & $\begin{array}{r}93.1 \\
6.2 \\
0.7\end{array}$ & $\begin{array}{l}47.6 \\
35.0 \\
20.1\end{array}$ \\
\hline
\end{tabular}

${ }^{1}$ Population data used to compute rates are from-U.S. Bureau of the Census: Estimates of the population of the United States by age, sex, and race, 1980 to 1985 . Current Population Reports. Series P-25, No. 985. Washington. U.S. Government Printing Office, Apr. 1986. 


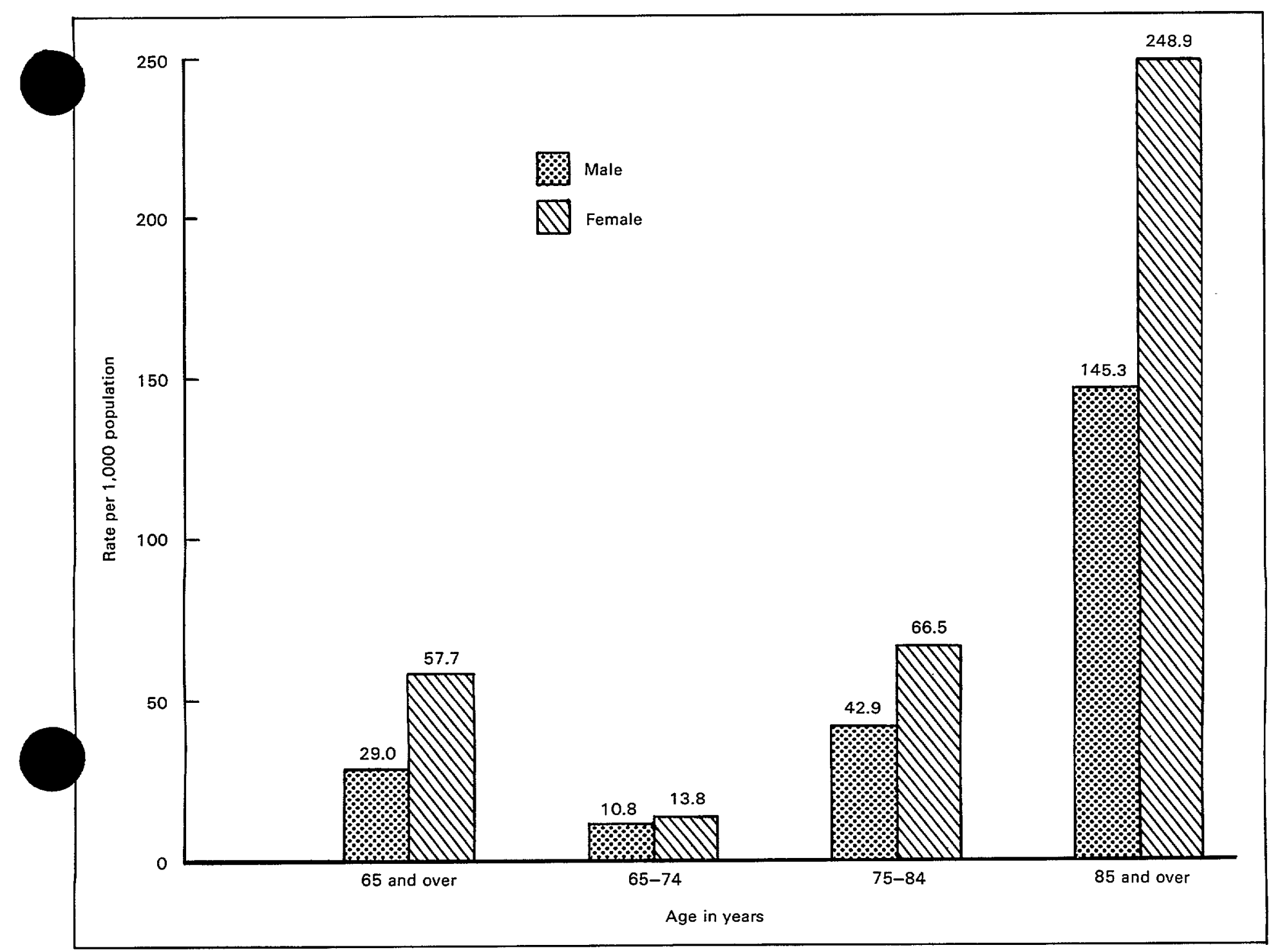

Figure 1. Number of nursing home residents per 1,000 population 65 years of age and over, by sex and age: United States, 1985

cent of white people, compared with 14 percent of black people, resided in nursing homes.

This lower use by elderly black people and those of other races may result from substitution of informal care at home for formal nursing home care. According to data from the 1982 Long-Term Care Survey, a higher proportion of elderly black people and people of other races than elderly white people were functionally impaired and remained in the community. Overall, 29 percent of the noninstitutionalized elderly who were of black or other races were functionally impaired in the activities of daily living or home management activities for at least 3 months, compared with only 19 percent of white people. ${ }^{6}$ Thus, elderly persons who were of black or other races were overrepresented among the noninstitutionalized most at risk of needing nursing home care. This finding suggests "the use of a more extended support system among black persons than among white persons." Other studies have shown that elderly black persons are more likely than elderly white persons to receive care at home. 7

The proportion of the elderly residing in nursing homes has not changed since the period 1973-74, when the first
NNHS was conducted (figure 2). An exception to this trend is the increase in the proportion of elderly black persons using nursing homes. During the period 1973-74, 2 percent of the elderly black population resided in nursing homes; in 1985, the proportion was nearly 4 percent. In contrast, the proportion of the elderly in nursing homes did not change from 1973-74 to 1985 for persons who are white or of other races. About 5 percent of elderly white persons and 2 percent of elderly persons of other races were residents of nursing homes throughout this period. The percent of elderly males and females as well as the percent of the elderly aged 65-74 and 75-84 years who resided in nursing homes also remained the same. The percent of persons 85 years and over, however, decreased: 25 percent of persons aged 85 years and over resided in nursing homes in the period 1973-74, compared with 22 percent in 1985 .

\section{Functional dependencies}

Because of the preponderance of very old residents in nursing homes, it is not surprising that many residents required assistance in performing or did not perform the basic activities 


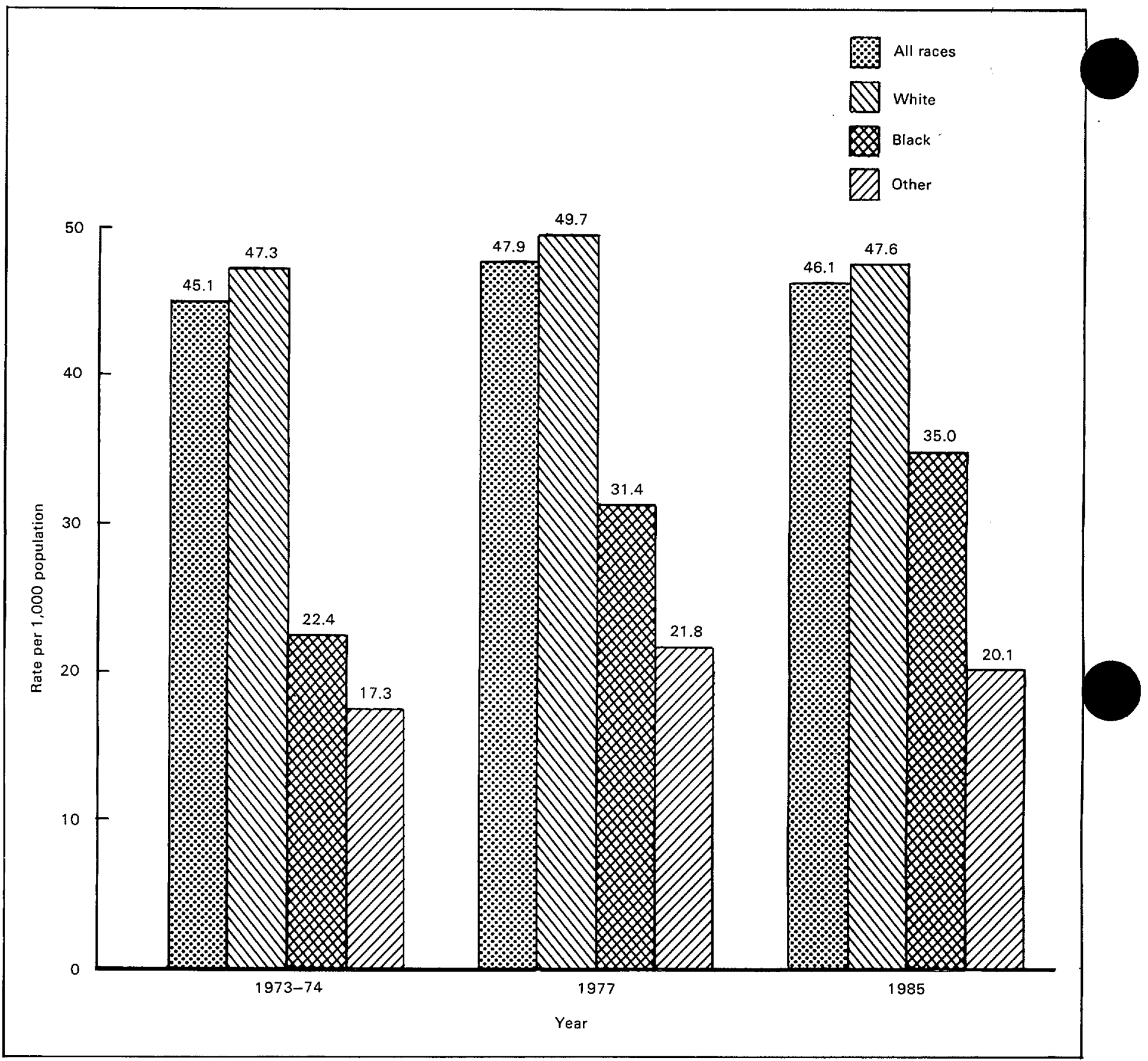

Figure 2. Number of nursing home residents per 1,000 population 65 years of age and over, by race: United States, 1973-74, 1977, and 1985

of daily living (ADL's), which are needed for independent living. The ADL's are bathing, dressing, using the toilet room, transferring in and out of a bed or chair, continence, and eating. In 1985,91 percent of elderly residents required assistance in bathing; 78 percent required assistance in dressing; 63 percent required assistance in using the toilet room; 63 percent required assistance in transferring from a bed or chair; 55 percent were incontinent (bowels, bladder, or both); and 40 percent required assistance in eating (table 2). These findings are consistent with earlier studies by Katz and Apkom, in which it was shown that loss of independence is most likely to occur in bathing and least likely to occur in eating. ${ }^{8}$
In general, elderly residents in nursing homes were more dependent in performing the ADL's in 1985 than in 1977. A larger proportion of elderly residents required assistance or had difficulty with bathing, using the toilet room, continence, and eating in 1985 than 1977 (tables 2 and 3). The exception to this trend was for dressing. The proportion of elderly residents requiring assistance in this ADL remained the same in both years. (Information about transferring from a bed or chair is not available from the 1977 NNHS.)

A partial explanation of the increased level of functional dependency is the shift in the age distribution of nursing home residents to the very old age group ( 85 years and over), noted 
Table 2. Percent of nursing home residents 65 years of age and over, by type of dependency in activities of daily living, percent distribution by number of dependencies, and average number of dependencies, according to age, sex, and race: United States, 1985

\begin{tabular}{|c|c|c|c|c|c|c|c|c|c|}
\hline \multirow[b]{2}{*}{ Dependency status } & \multirow[b]{2}{*}{ Total } & \multicolumn{3}{|c|}{ Age } & \multicolumn{2}{|c|}{ Sex } & \multicolumn{3}{|c|}{ Race } \\
\hline & & $\begin{array}{c}65-74 \\
\text { years }\end{array}$ & $\begin{array}{l}75-84 \\
\text { years }\end{array}$ & $\begin{array}{l}85 \text { years } \\
\text { and over }\end{array}$ & Male & Female & White & Black & Other \\
\hline Type of dependency & \multicolumn{9}{|c|}{ Percent } \\
\hline $\begin{array}{l}\text { Requires assistance in bathing. } \ldots \ldots \ldots \ldots \ldots \ldots \ldots \ldots \\
\text { Requires assistance in dressing. } \ldots \ldots \ldots \ldots \ldots \ldots \ldots \\
\text { Requires assistance in using toilet room. } \\
\text { Requires assistance in transferring }{ }^{1} \ldots \ldots \ldots \ldots \ldots \\
\text { Continence-difficulty with bowel and/or bladder }\end{array}$ & $\begin{array}{l}91.2 \\
77.7 \\
63.3 \\
62.7\end{array}$ & $\begin{array}{l}84.8 \\
70.2 \\
56.6 \\
52.1\end{array}$ & $\begin{array}{l}90.3 \\
75.9 \\
60.3 \\
59.7\end{array}$ & $\begin{array}{l}94.1 \\
81.9 \\
68.2 \\
69.0\end{array}$ & $\begin{array}{l}86.9 \\
71.5 \\
56.2 \\
55.3\end{array}$ & $\begin{array}{l}92.6 \\
79.7 \\
65.7 \\
65.2\end{array}$ & $\begin{array}{l}90.9 \\
77.3 \\
62.9 \\
62.2\end{array}$ & $\begin{array}{l}94.2 \\
83.7 \\
68.6 \\
70.2\end{array}$ & $\begin{array}{l}91.5 \\
72.9 \\
61.4 \\
60.9\end{array}$ \\
\hline 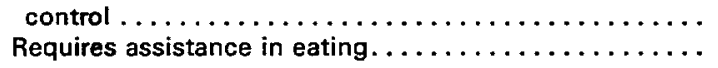 & $\begin{array}{l}54.5 \\
40.4\end{array}$ & $\begin{array}{l}42.9 \\
33.4\end{array}$ & $\begin{array}{l}55.0 \\
39.1\end{array}$ & $\begin{array}{l}58.1 \\
44.0\end{array}$ & $\begin{array}{l}51.9 \\
34.8\end{array}$ & $\begin{array}{l}55.3 \\
42.3\end{array}$ & $\begin{array}{l}54.1 \\
40.0\end{array}$ & $\begin{array}{l}59.9 \\
47.9\end{array}$ & $\begin{array}{l}47.6 \\
32.1\end{array}$ \\
\hline Number of dependencies & \multicolumn{9}{|c|}{ Percent distribution } \\
\hline 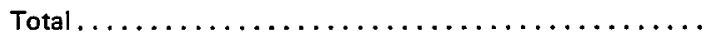 & 100.0 & 100.0 & 100.0 & 100.0 & 100.0 & 100.0 & 100.0 & 100.0 & 100.0 \\
\hline 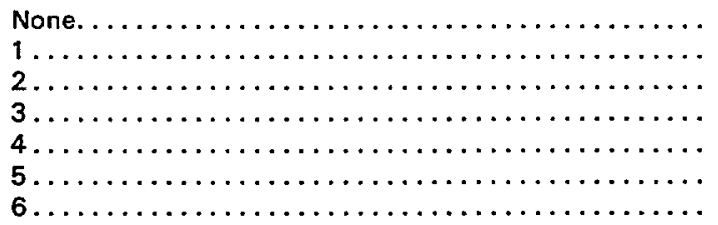 & $\begin{array}{r}7.6 \\
11.0 \\
9.9 \\
7.8 \\
13.5 \\
19.8 \\
30.4\end{array}$ & $\begin{array}{r}13.2 \\
14.0 \\
11.2 \\
7.3 \\
13.8 \\
16.6 \\
23.9\end{array}$ & $\begin{array}{r}8.6 \\
11.6 \\
9.6 \\
8.7 \\
12.8 \\
19.4 \\
29.2\end{array}$ & $\begin{array}{r}4.8 \\
9.4 \\
9.6 \\
7.2 \\
13.9 \\
21.3 \\
33.8\end{array}$ & $\begin{array}{r}11.8 \\
12.5 \\
10.0 \\
8.6 \\
12.6 \\
18.7 \\
25.7\end{array}$ & $\begin{array}{r}6.2 \\
10.5 \\
9.8 \\
7.5 \\
13.8 \\
20.2 \\
32.0\end{array}$ & $\begin{array}{r}7.8 \\
11.3 \\
10.0 \\
7.6 \\
13.4 \\
19.9 \\
30.1\end{array}$ & $\begin{array}{r}4.8 \\
6.5 \\
8.0 \\
11.4 \\
14.4 \\
18.9 \\
35.9\end{array}$ & $\begin{array}{r}* 8.5 \\
* 15.8 \\
* 8.8 \\
* 5.5 \\
{ }^{*} 16.6 \\
{ }^{*} 18.6 \\
{ }^{*} 26.3\end{array}$ \\
\hline & \multicolumn{9}{|c|}{ Average number } \\
\hline Average number of dependencies $\ldots \ldots \ldots \ldots \ldots \ldots$ & 3.9 & 3.4 & 3.8 & 4.2 & 3.6 & 4.0 & 3.9 & 4.2 & 3.7 \\
\hline
\end{tabular}

${ }^{\mathfrak{I}}$ Transferring refers to getting in or out of a bed or chair.

Table 3. Percent of nursing home residents 65 years of age and over, by age and type of dependency in activities of daily living: United States, 1977

\begin{tabular}{llccc}
\hline & All ages & & & \\
65 years & $65-74$ & $75-84$ & 85 years \\
Type of dependency & and over & years & years & and over \\
\hline
\end{tabular}

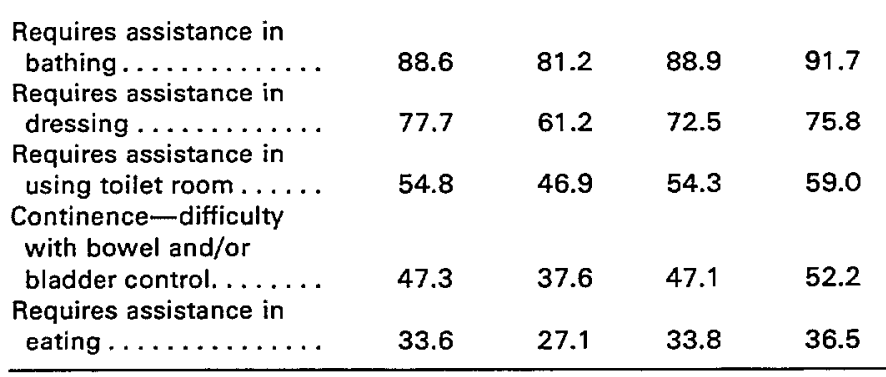

earlier. However, as tables 2 and 3 show, the proportion of residents functionally dependent in each $A D L$ was generally higher in 1985 than in 1977 even when age was held constant. For example, a larger proportion of residents aged 85 years and over were dependent in bathing, dressing, using the toilet room, continence, and eating in 1985 than in 1977. Another explanation is the impact of medicare policy on nursing home care. Under the medicare prospective payment system, instituted in 1983, hospitals are encouraged to reduce patient length onfou of stay. Patients released earlier under this new system may require a higher level of care in the nursing home than they would have needed if they had stayed longer in the hospital..$^{9}$

In general, dependency in ADL's increases with age. In 1985 , the percent of residents requiring assistance in bathing increased from 85 percent for residents $05-74$ years to 94 percent for residents 85 years and over. Similarly, difficulty with bowel or bladder control increased from 43 percent for residents 65-74 years to 58 percent for residents 85 years and over. Because female residents were older, on the average, than male residents, they tended to require assistance in ADL's more often than males did. A greater proportion of female than male elderly residents needed assistance in bathing, dressing, using the toilet room, transferring from a bed or chair, and eating. There was no statistically significant difference in the percent incontinent by sex. Elderly black residents also needed assistance in ADL's more often than elderly white residents did. This was the case in five of the six ADL's. There was no statistically significant difference in the percent incontinent by race.

The six activities of daily living may be summarized into a single measure of ADL dependency by summing the number of activities in which a resident required assistance. ${ }^{8}$ In 1985, 30 percent of elderly residents required assistance in all six ADL's, and only 8 percent were independent in all six activities. The mean number of dependencies was 3.9. The mean number of ADL dependencies increased with age from an average of 3.4 dependencies among residents $65-74$ years to 4.2 dependencies among those 85 years and over. Females tended to be more functionally dependent than males. Overall, elderly females had an average of 4.0 ADL dependencies, and elderly males had an average of 3.6. Elderly black residents also tended to be more functionally dependent than elderly white residents. The average number of $\mathrm{ADL}$ dependencies was 4.2 among elderly black residents, compared with 3.9 among elderly white residents. Thus, the data show a greater need for care in nursing homes among female and black residents. In the case of females, 
this is correlated with higher use of nursing homes. This is not the case, however, for elderly black persons.

Although it is possible that nursing home policy may preclude the resident from performing ADL's without assistance, the overwhelming need for assistance in ADL's among nursing home residents suggests that this dependency may have been a reason for entering the nursing home. (The importance of functional status as a reason for nursing home admission was also found in a study of medicare recipients. ${ }^{10}$ ) In contrast, the need for such assistance is minimal among the noninstitutionalized elderly. According to data from the Supplement on Aging to the 1984 National Health Interview Survey, 6 percent of the noninstitutionalized elderly received assistance in bathing; 4 percent, in dressing; 2 percent, in using the toilet room; 3 percent, in transferring from a bed or chair; and 1 percent, in eating (table 4). Data from the 1982 Long-Term Care Survey, which covered noninstitutionalized medicare enrollees most at risk of needing long-term care (people functionally impaired in ADL's or the instrumental activities of daily living for at least 3 months), indicate a lower need for assistance in ADL's than was found among nursing home residents. In 1982,42 percent of the elderly impaired living in the community required assistance in bathing, 20 percent required assistance in dressing, 21 percent required assistance in using the toilet room, 26 percent required assistance in transferring from a bed or chair, and 6 percent required assistance in eating. ${ }^{6}$ Additional insights should be provided on the reasons for admission when data from the nextof-kin component are available.

\section{Cognitive impairment}

Another reason for nursing home placement that is cited in the literature is deteriorating cognitive functioning. ${ }^{11}$ In 1985 , 63 percent of elderly residents were disoriented or memory impaired to such a degree that performance of the basic ADL's, mobility, and other tasks were impaired nearly every day. Disorientation or memory impairment was defined as being unable to remember dates or time, unable to identify familiar locations or people, unable to recall important aspects of recent events, or unable to make straightforward judgments. Major causes

Table 4. Percent of persons 65 years of age and over, by whether nursing home resident or noninstitutionalized and type of dependency in selected activities of daily living: United States, 1984 and 1985

\begin{tabular}{|c|c|c|}
\hline Type of dependency & $\begin{array}{l}\text { Nursing home } \\
\text { residents, } 1985\end{array}$ & $\begin{array}{c}\text { Noninstitutionalized } \\
\text { population, } 11984\end{array}$ \\
\hline Requires assistance in: & \multicolumn{2}{|c|}{ Percent } \\
\hline Bathing. . . . . . . . . . & 91.2 & 6.0 \\
\hline Dressing . . . . . . . . . & 77.7 & 4.3 \\
\hline Using toilet room. . . . . . . . & 63.3 & 2.2 \\
\hline Transferring $^{2} \ldots \ldots \ldots \ldots$ & 62.7 & 2.8 \\
\hline Eating $\ldots \ldots \ldots \ldots \ldots$ & 40.4 & 1.1 \\
\hline
\end{tabular}

'Data are from the National Center for Health Statistics, D. Dawson, G. Hendershot and J. Fulton: Aging in the eighties, functional limitations of individuals age 65 years and over. Advance Data From Vital and Health Statistics. No. 133. DHHS Pub. No. (PHS) 87-1250. Public Health Service. Hyattsville, Md., April 30, 1987. Percent of the noninstitutionalized elderly dependent in activities of daily living is a measure of those who received help rather than those needing it.

${ }^{2}$ Transferring refers to getting in or out of a bed or chair. of disorientation or memory impairment in the elderly are senile dementia and chronic organic brain syndrome. In 1985, 47 percent of elderly residents were reported to have at least one of these conditions (table 5). Sixty-six percent of elderly residents who were disoriented or memory impaired were also reported to have senile dementia or chronic organic brain syndrome.

In general, disorientation or memory impairment increased with age: 56 percent of residents $65-74$ years of age had memory impairment or disorientation, compared with 67 percent of those 85 years and over. Elderly female residents were memory impaired or disoriented more often than elderly male residents were- -64 percent and 59 percent, respectively. This finding may be related to females' greater longevity. Although it appears that elderly black residents were memory impaired more often than elderly white residents were ( 70 percent, compared with 62 percent of elderly white residents), the difference was not statistically significant. Similar patterns were also found for residents with senile dementia or chronic organic brain syndrome when examined by age, sex, and race.

\section{Marital status at admission}

The marital status of residents may have influenced the decision to enter the nursing home because persons without spouses may not have anyone living with them to provide personal care services that would allow them to stay in the community longer. In 1985 the majority of elderly residents were without spouses at the time of admission to the nursing home. 65 percent were widowed, 6 percent were divorced or separated, and 14 percent had never married (table 6). In contrast, only 16 percent of elderly residents were married at the time of admission. The likelihood of being widowed increased with age, and the proportion who were married decreased with age. In

Table 5. Percent of nursing home residents 65 years of age and over, by whether they had disorientation or memory impairment and senile dementia or chronic organic brain syndrome, age, sex, and race: United States, 1985

\begin{tabular}{|c|c|c|}
\hline Age, sex, and race & $\begin{array}{l}\text { Disorientation } \\
\text { or memory } \\
\text { impairment }\end{array}$ & $\begin{array}{c}\text { Senile dementia } \\
\text { or chronic } \\
\text { organic brain } \\
\text { syndrome }\end{array}$ \\
\hline & \multicolumn{2}{|c|}{ Percent } \\
\hline Total. . . . . . . . . . . . . . . & 62.6 & 47.0 \\
\hline \multicolumn{3}{|l|}{ Age } \\
\hline $\begin{array}{l}65-74 \text { years } \ldots \ldots \ldots \ldots \ldots \ldots \\
75-84 \text { years } \ldots \ldots \ldots \ldots \ldots \ldots \\
85 \text { years and over } \ldots \ldots \ldots \ldots \ldots \ldots\end{array}$ & $\begin{array}{l}55.7 \\
60.8 \\
66.6\end{array}$ & $\begin{array}{l}34.0 \\
45.4 \\
52.9\end{array}$ \\
\hline \multicolumn{3}{|l|}{ Sex } \\
\hline $\begin{array}{l}\text { Male. } \ldots \ldots \ldots \ldots \ldots \ldots \ldots \ldots \ldots \\
\text { Female } \ldots \ldots \ldots \ldots \ldots \ldots \ldots\end{array}$ & $\begin{array}{l}58.8 \\
63.9\end{array}$ & $\begin{array}{l}42.1 \\
48.6\end{array}$ \\
\hline \multicolumn{3}{|l|}{ Race } \\
\hline $\begin{array}{l}\text { White } \ldots \ldots \ldots \ldots \ldots \ldots \ldots \ldots \ldots \\
\text { Black } \ldots \ldots \ldots \ldots \ldots \ldots \ldots \ldots \ldots \ldots \\
\text { Other } \ldots \ldots \ldots \ldots \ldots \ldots\end{array}$ & $\begin{array}{l}62.2 \\
69.5 \\
56.2\end{array}$ & $\begin{array}{r}46.8 \\
51.4 \\
* 35.2\end{array}$ \\
\hline
\end{tabular}


Table 6. Percent distribution of nursing home residents 65 years of age and over by marital status at admission and percent with living children, according to age, sex, and race: United States, 1985

\begin{tabular}{|c|c|c|c|c|c|c|}
\hline \multirow[b]{2}{*}{ Age, sex, and race } & \multirow[b]{2}{*}{ Total } & \multicolumn{4}{|c|}{ Marital status at admission } & \multirow[b]{2}{*}{$\begin{array}{l}\text { Proportion with } \\
\text { living children }\end{array}$} \\
\hline & & Married & Widowed" & $\begin{array}{l}\text { Divorced or } \\
\text { separated }\end{array}$ & $\begin{array}{l}\text { Never } \\
\text { married }\end{array}$ & \\
\hline & \multicolumn{5}{|c|}{ Percent distribution } & Percent \\
\hline 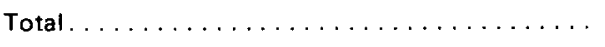 & 100.0 & 16.4 & 64.2 & 5.9 & 13.5 & 63.1 \\
\hline \multicolumn{7}{|l|}{ Age } \\
\hline 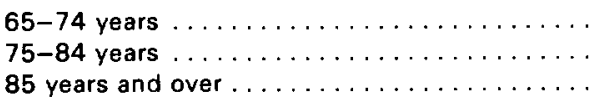 & $\begin{array}{l}100.0 \\
100.0 \\
100.0\end{array}$ & $\begin{array}{l}22.8 \\
19.2 \\
11.8\end{array}$ & $\begin{array}{l}35.9 \\
60.9 \\
77.2\end{array}$ & $\begin{array}{r}14.2 \\
6.5 \\
2.3\end{array}$ & $\begin{array}{r}27.2 \\
13.4 \\
8.6\end{array}$ & $\begin{array}{l}50.1 \\
62.2 \\
68.6\end{array}$ \\
\hline \multicolumn{7}{|l|}{ Sex } \\
\hline $\begin{array}{l}\text { Male } \ldots \ldots \ldots \ldots \ldots \ldots \ldots \ldots \ldots \ldots \ldots \ldots \ldots \ldots \\
\text { Female } \ldots \ldots \ldots \ldots \ldots \ldots \ldots \ldots\end{array}$ & $\begin{array}{l}100.0 \\
100.0\end{array}$ & $\begin{array}{l}32.5 \\
11.0\end{array}$ & $\begin{array}{l}36.7 \\
73.6\end{array}$ & $\begin{array}{r}10.1 \\
4.4\end{array}$ & $\begin{array}{l}20.6 \\
11.0\end{array}$ & $\begin{array}{l}55.7 \\
65.7\end{array}$ \\
\hline \multicolumn{7}{|l|}{ Race } \\
\hline 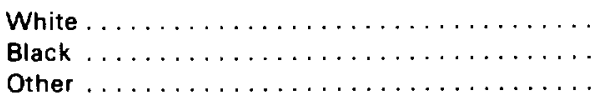 & $\begin{array}{l}100.0 \\
100.0 \\
100.0\end{array}$ & $\begin{array}{r}16.6 \\
13.8 \\
* 14.9\end{array}$ & $\begin{array}{l}64.4 \\
61.9 \\
64.9\end{array}$ & $\begin{array}{l}5.6 \\
9.8\end{array}$ & $\begin{array}{r}13.3 \\
14.5 \\
* 20.2\end{array}$ & $\begin{array}{l}64.5 \\
41.8 \\
68.1\end{array}$ \\
\hline
\end{tabular}

${ }^{1}$ A small number of persons of unknown marital status are included.

the group 65-74 years, 36 percent of residents were widowed; 77 percent of residents 85 years and over were widowed. Elderly female residents were more likely to be widowed ( 74 percent) than elderly male residents ( 37 percent). Elderly males were more likely to be married ( 33 percent) than elderly female resiits ( 11 percent).

The tendency of persons without spouses to enter nursing homes is highlighted by comparing the marital status of the functionally impaired elderly living in the community with that of elderly nursing home residents. The proportion married was larger among the functionally impaired elderly living in the community (44 percent) than among elderly nursing home residents ( 16 percent). Thus, 84 percent of the elderly in nursing homes were without spouses, compared with 56 percent of the functionally impaired living in the community. ${ }^{6}$

\section{Presence of living children}

Data on whether nursing home residents had living children were collected for the first time in the 1985 NNHS. Among elderly nursing home residents, the majority ( 63 percent) had living children. The proportion of residents with children increased with age and was greater for female residents ( 66 percent) than male residents ( 56 percent). The trends among residents with children mirror the increasing utilization rates by age and the greater nursing home use by elderly women. Additionally, these trends appear to contradict the notion that the lack of children, which is a proxy measure for the lack of a social support network, is a risk factor for nursing home institutionalization. The finding that most elderly residents had children does not explain hy itself why people enter nursing homes because this variable

onfounded by several factors. First, it is not known whether : residents' children lived close enough to provide care and, if they did, whether they were physically able to provide care. Although 69 percent of residents 85 years and over had children, their children were probably in their sixties and may not have been physically able to care for their aging parents. Furthermore, for many residents, admission to the current nursing home was not from the community but from another health institution. As will be discussed in the next section, more than one-half of elderly residents were transferred to the nursing home from another health facility. For these residents, obtaining appropriate continuing care was a deciding factor in entering the current nursing home. Their children may not have been able to provide adequate informal care in the home. Further insights on this issue should be gained when the next-of-kin data on the sample residents are available.

There was one exception to this trend. Only 42 percent of elderly black residents had children, compared with 65 percent of elderly white residents. In the 1982 Long-Term Care Survey it was found that noninstitutionalized elderly black persons who were functionally impaired were more likely to live with children than functionally impaired elderly white persons were. ${ }^{6}$

\section{Living arrangements prior to nursing home admission}

The living arrangements of residents prior to admission reflect both the amount of support given in the environment in which they previously lived and their health. A majority of the residents ( 57 percent) were transferred from another health facility (table 7). The most common type of health facility transferred from was a short-stay hospital (39 percent). Only 12 percent of residents were transferred from another nursing home, and 3 percent were transferred from some type of mental facility (mental hospital, facility for the mentally retarded, psychiatric unit of a short-stay hospital, or mental health center). The proportion of elderly residents admitted from a short-stay hospital in 1985 (39 percent) was a significant increase from the proportion in 1977 ( 34 percent). This finding may also be related to the introduction of the medicare prospective payment system, under which hospitals have a strong incentive for early 
Table 7. Percent distribution of nursing home residents 65 years of age and over by living arrangement prior to admission, according to age, sex, and race: United States, 1985

\begin{tabular}{|c|c|c|c|c|c|c|c|c|c|}
\hline \multirow[b]{2}{*}{ Living arrangement prior to admission } & \multirow[b]{2}{*}{ Total } & \multicolumn{3}{|c|}{ Age } & \multicolumn{2}{|c|}{ Sex } & \multicolumn{3}{|c|}{ Race } \\
\hline & & $\begin{array}{c}65-74 \\
\text { years }\end{array}$ & $\begin{array}{c}75-84 \\
\text { years }\end{array}$ & $\begin{array}{l}85 \text { years } \\
\text { and over }\end{array}$ & Male & Female & White & Black & Other \\
\hline & \multicolumn{9}{|c|}{ Percent distribution } \\
\hline All living arrangements $\ldots \ldots \ldots \ldots \ldots \ldots \ldots$ & 100.0 & 100.0 & 100.0 & 100.0 & 100.0 & 100.0 & 100.0 & 100.0 & 100.0 \\
\hline Private or semiprivate residence $\ldots \ldots \ldots \ldots \ldots$ & 40.0 & 29.2 & 40.5 & 43.3 & 36.3 & 41.2 & 40.5 & 31.9 & 35.6 \\
\hline 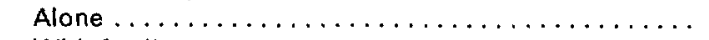 & 14.7 & 8.2 & 14.7 & 17.0 & 11.6 & 15.8 & 15.2 & 6.9 & $* 15.5$ \\
\hline With family members $\ldots \ldots \ldots \ldots \ldots \ldots \ldots$ & 18.9 & 16.0 & 19.8 & 19.2 & 19.3 & 18.8 & 18.9 & 19.0 & $* 15.5$ \\
\hline With nonfamily members $\ldots \ldots \ldots \ldots \ldots \ldots \ldots$ & 3.4 & *3.1 & 3.3 & 3.5 & 3.2 & 3.4 & 3.3 & 3.9 & $* 2.0$ \\
\hline Unknown if with others. . . . . . . . . . . . . . & 3.0 & 1.8 & 2.7 & 3.7 & 2.2 & 3.3 & 3.1 & $* 2.1$ & $* 2.5$ \\
\hline Another health facility. .................. & 57.0 & 67.7 & 56.5 & 53.6 & 60.4 & 55.9 & 56.5 & 65.2 & 59.0 \\
\hline Another nursing home $\ldots \ldots \ldots \ldots \ldots \ldots$ & 12.2 & 12.9 & 12.6 & 11.5 & 13.1 & 11.8 & 12.4 & 9.2 & *9.7 \\
\hline General or short-stay hospital' . . . . . . . . . & 38.7 & 39.5 & 38.2 & 38.9 & 35.2 & 40.0 & 37.9 & 49.5 & 49.4 \\
\hline Mental facility ${ }^{2} \ldots \ldots \ldots \ldots \ldots \ldots \ldots \ldots$ & 3.0 & 7.6 & 3.2 & 1.1 & 5.0 & 2.3 & 3.1 & $* 1.8$ & - \\
\hline 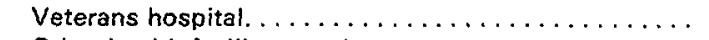 & 1.4 & 4.6 & 0.9 & 0.7 & 5.4 & $* 0.0$ & 1.5 & ${ }^{*} 0.9$ & - \\
\hline Other health facility or unknown $\ldots \ldots \ldots \ldots \ldots$ & 1.9 & 3.3 & 1.9 & 1.4 & 1.9 & 1.9 & 1.8 & *3.8 & - \\
\hline Unknown or other arrangement $\ldots \ldots \ldots \ldots \ldots \ldots$ & 2.9 & 2.9 & 2.7 & 3.0 & 3.1 & 2.8 & 2.9 & *2.9 & ${ }^{*} 5.4$ \\
\hline
\end{tabular}

'Psychiatric units of hospitals are excluded.

${ }^{2}$ Mental hospitals, facilities for the mentally retarded, general or short-stay hospital psychiatric units, and mental health centers are included.

discharge of patients needing long-term care services. ${ }^{9}$ Further analysis of this issue will be presented in a later report.

The increasing proportion of residents transferred from short-stay hospitals to nursing homes also reflects the increasing role hospitals play in the provision of care to the elderly. For example, in the 1985 NNHS it was found that 22 percent of elderly residents were hospitalized for acute episodes of illness while still a resident of the nursing home. Thirteen percent of elderly residents had only one hospitalization, and 9 percent had two or more hospital stays (table 8). Hospitalizations of elderly residents were less likely among those who were admitted to the nursing home from a short-stay hospital, only 14 percent of whom had a subsequent hospitalization while a resident. In contrast, 27 percent of elderly residents not admitted from a short-stay hospital were hospitalized while a resident of the home.

When examined by age, the proportion of elderly residents transferred from a short-stay hospital or nursing home did not vary. Elderly female residents, however, were more likely to be admitted from a short-stay hospital (40 percent) than elderly male residents were ( 35 percent). In addition, a higher propor-

Table 8. Percent distribution of nursing home residents 65 years of age and over by number of hospital admissions while a resident, according to whether admitted from a short-stay hospital: United States, 1985

\begin{tabular}{|c|c|c|c|}
\hline $\begin{array}{c}\text { Number of hospital stays } \\
\text { while a resident }\end{array}$ & Total & $\begin{array}{l}\text { Admitted } \\
\text { from } \\
\text { short-stay } \\
\text { hospital }\end{array}$ & $\begin{array}{l}\text { Not admitted } \\
\text { from } \\
\text { short-stay } \\
\text { hospital }\end{array}$ \\
\hline & \multicolumn{3}{|c|}{ Percent distribution } \\
\hline Total. ................. & 100.0 & 100.0 & 100.0 \\
\hline $\begin{array}{l}\text { None }{ }^{1} \ldots \ldots \ldots \ldots \ldots \ldots \ldots \ldots \ldots \\
1 \ldots \ldots \ldots \ldots \ldots \ldots \ldots \\
2 \text { or more } \ldots \ldots \ldots \ldots \ldots \ldots \ldots\end{array}$ & $\begin{array}{r}77.7 \\
13.1 \\
9.1\end{array}$ & $\begin{array}{r}85.5 \\
9.2 \\
5.2\end{array}$ & $\begin{array}{l}72.8 \\
15.6 \\
11.6\end{array}$ \\
\hline
\end{tabular}

iA small number of persons with unknown number of hospital stays are tion of elderly black residents ( 50 percent) than elderly white residents ( 38 percent) were transferred from a short-stay hospital. These findings appear to be correlated with the generally more dependent functional status of elderly women and black residents.

Forty percent of elderly residents were admitted from private or semiprivate residence; 15 percent had lived alc prior to the nursing home admission, 19 percent lived with fam. members, and 3 percent lived with persons who were not family members. Residents 75 years and over were more likely than those $65-74$ years to have lived alone prior to being admitted to the nursing home. Elderly female residents were more likely to have lived alone ( 16 percent) than elderly male residents (12 percent). Elderly black residents were less likely ( 7 percent) than elderly white residents (15 percent) to have lived alone prior to admission. This may result from the tendency of functionally impaired elderly black people to "draw on a more extended range of relationships in their living arrangement than white persons."' 6

\section{Primary source of payment at admission}

Data on sources of funds used to no. nursing home care provide a rough measure of .,usents' income sources because public funds for nursmg home care under certain government programs are available only to those who cannot afford to pay for such care. The medicaid program, for example, is a joint Federal-State program providing medical benefits to persons who qualify for welfare and to some of the "medically needy" (those who would be on welfare if their incomes were a little lower). The State-set criteria for medicaid eligibility vary from State to State but cover most poor people in the UniteStates, ${ }^{12}$

Information on the payment sources used during the moth of admission was collected for the first time in the $1985 \mathrm{NNH}_{2}$ Table 9 shows the primary payment source used by elderl residents in the home 1 month or more. One-half of elder 
Table 9. Percent distribution of nursing home residents 65 years of age and over by primary source of payment at admission, according to age, sex, and race: United States, 1985

\begin{tabular}{|c|c|c|c|c|c|c|c|}
\hline \multirow[b]{3}{*}{ Age, sex, and race } & \multicolumn{7}{|c|}{ Primary scurce of payment at admission } \\
\hline & \multirow[b]{2}{*}{ All sources } & \multirow[b]{2}{*}{$\begin{array}{l}\text { Own income or } \\
\text { family support }\end{array}$} & \multirow[b]{2}{*}{ Medicare } & \multicolumn{2}{|c|}{ Medicaid payment for- } & \multirow{2}{*}{$\begin{array}{c}\text { Other } \\
\text { government } \\
\text { assistance or } \\
\text { welfare }\end{array}$} & \multirow[b]{2}{*}{$\begin{array}{l}\text { All other } \\
\text { sources }\end{array}$} \\
\hline & & & & $\begin{array}{l}\text { Skilled } \\
\text { nursing }\end{array}$ & $\begin{array}{l}\text { Intermediate } \\
\text { care }\end{array}$ & & \\
\hline & \multicolumn{7}{|c|}{ Percent distribution } \\
\hline Total $\ldots \ldots \ldots \ldots \ldots \ldots \ldots \ldots$ & 100.0 & 49.8 & 4.9 & 13.9 & 26.2 & 2.7 & 2.5 \\
\hline \multicolumn{8}{|l|}{ Age } \\
\hline $\begin{array}{l}65-74 \text { years } \ldots \ldots \ldots \ldots \ldots \ldots \ldots \ldots \ldots \ldots \ldots \ldots \\
75-84 \text { years } \ldots \ldots \ldots \ldots \ldots \ldots \ldots \ldots \ldots \ldots \ldots \ldots \ldots \\
85 \text { years and over. } \ldots \ldots \ldots \ldots \ldots \ldots \ldots \ldots \ldots\end{array}$ & $\begin{array}{l}100.0 \\
100.0 \\
100.0\end{array}$ & $\begin{array}{l}39.0 \\
51.2 \\
52.4\end{array}$ & $\begin{array}{l}4.7 \\
5.2 \\
4.6\end{array}$ & $\begin{array}{l}13.9 \\
13.5 \\
14.3\end{array}$ & $\begin{array}{l}31.5 \\
25.3 \\
25.1\end{array}$ & $\begin{array}{l}5.5 \\
2.6 \\
1.9\end{array}$ & $\begin{array}{l}5.4 \\
2.3 \\
1.7\end{array}$ \\
\hline \multicolumn{8}{|l|}{ Sex } \\
\hline $\begin{array}{l}\text { Male } \ldots \ldots \ldots \ldots \ldots \ldots \ldots \ldots \ldots \ldots \ldots \ldots \ldots \ldots \ldots \ldots \ldots \ldots \ldots \ldots \\
\text { Femate. . } \ldots \ldots \ldots \ldots \ldots \ldots \ldots \ldots\end{array}$ & $\begin{array}{l}100.0 \\
100.0\end{array}$ & $\begin{array}{l}50.9 \\
49.5\end{array}$ & $\begin{array}{l}4.8 \\
4.9\end{array}$ & $\begin{array}{l}11.9 \\
14.6\end{array}$ & $\begin{array}{l}23.7 \\
27.0\end{array}$ & $\begin{array}{l}4.0 \\
2.3\end{array}$ & $\begin{array}{l}4.8 \\
1.7\end{array}$ \\
\hline \multicolumn{8}{|l|}{ Race } \\
\hline 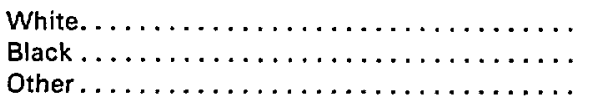 & $\begin{array}{l}100.0 \\
100.0 \\
100.0\end{array}$ & $\begin{array}{r}52.2 \\
17.1 \\
* 32.0\end{array}$ & $\begin{array}{r}4.9 \\
5.0\end{array}$ & $\begin{array}{l}13.2 \\
21.1 \\
39.3\end{array}$ & $\begin{array}{r}24.6 \\
49.3 \\
* 28.7\end{array}$ & $\begin{array}{r}2.6 \\
* 5.3\end{array}$ & $\begin{array}{r}2.5 \\
* 2.2\end{array}$ \\
\hline
\end{tabular}

NOTE: Data cover only persons who were residents for 1 month or more.

residents relied primarily on their own income or family support to pay for the first month in the nursing home, and 40 percent relied primarily on the medicaid program to pay for care. dicaid finances both skilled nursing and intermediate care vices in nursing homes. At the time of admission, 26 percent of elderly residents received intermediate care and 14 percent received skilled nursing care through the medicaid program. Only 5 percent of elderly residents relied on medicare. Extended care benefits under medicare are limited to 100 days following a hospital stáy of at least 3 days. Three percent of elderly residents relied on other government assistance or welfare, and another 3 percent relied on other payment sources. Overall, 48 percent of elderly residents relied on some form of public funds to pay for their stay at the time of admission.

There were differences in primary payment source by age. Residents 75 years of age and over were more likely to use their own income or family support for primary payment than were residents aged 65-74 years. Of residents $75-84$ years and 85 years and over, 51 and 52 percent, respectively, relied on their own income or family support to pay for care, compared with 39 percent of residents $65-74$ years. Medicaid was the primary payment source for a larger proportion of residents $65-74$ years ( 45 percent) than residents aged $75-84$ years ( 39 percent) or 85 years and over ( 39 percent). The primary payment source also varied by sex. A larger proportion of elderly females ( 42 percent) than elderly males ( 36 percent) relied on medicaid for payment.

There were major differences in the patterns of payment at admission by race. Elderly black residents were almost twice ikely to use medicaid as the primary source of payment (70 cent) as elderly white residents were (38 percent). Conversely, elderly white residents were more likely to use their own income or family support as their primary payment source (52 percent) than elderly black residents were (17 percent).
The differences in payment source by sex and race reflect the generally lower income of elderly women and elderly black people in the noninstitutionalized population, ${ }^{13}$ and in particular among the functionally impaired elderly living in the community. In 1982, 46 percent of elderly females who were functionally impaired and living in the community had family incomes of less than $\$ 7,000$, compared with 31 percent of their male counterparts. Similarly, 61 percent of functionally impaired elderly black persons had family incomes of less than $\$ 7,000$, compared with 37 percent of functionally impaired elderly white persons. (Family income included income of the functionally impaired individual and all members living with him or her.) $)^{6}$

\section{Conclusions}

On any given day during the survey period for the 1985 NNHS, about 5 percent of the elderly were residents of nursing homes. Use of nursing homes increased with age for both sexes but was greater for females than for males, especially in the older age groups. Use of nursing homes was lower for elderly persons who were black or of other races than for white persons. These trends have remained constant since the period 1973-74, when the first NNHS was conducted, with the exception of an increase in the use of nursing homes by elderly black persons and a decrease in use by those aged 85 years and over.

Examination of some health and social characteristics revealed that dependency in ADL's was widely prevalent among elderly nursing home residents but much rarer among the noninstitutionalized elderly. The lack of available caregivers may have been a confounding factor for the preponderance of persons without spouses in nursing homes. The role of the residents' children or their living arrangements prior to admission 
in the decision to enter a nursing home is not clear from the data examined. The need for continuing care in a nursing home and the availability and willingness of the residents' children to provide informal home care are issues that need further examination before conclusions can be drawn. These issues will be examined in future reports in which data from the next-ofkin component are presented. The lower use of nursing homes by elderly black persons appears to be related to a greater substitution of informal care at home for formal nursing home care.

In this report, data on the primary source of payment for care used by residents during the month of admission were also presented. The data show that in 1985 one-half of elderly resi-

\section{References}

${ }^{1}$ National Center for Health Statistics, E. Hing: Characteristics of nursing home residents, health status, and care received, National Nursing Home Survey, United States, May-December 1977. Vital and Health Statistics. Series 13, No. 51. DHHS Pub. No. (PHS) 811712. Public Health Service. Washington. U.S. Government Printing Office, Apr. 1981.

${ }^{2}$ National Center for Health Statistics, D. Roper: Nursing and related care homes as reported from the 1982 National Master Facility Inventory Survey. Vital and Health Statistics. Series 14, No. 32. DHHS Pub. No. (PHS) 86-1827. Public Health Service. Washington. U.S. Government Printing Office, Sept. 1986.

${ }^{3}$ National Center for Health Statistics, G. Strahan: Nursing home characteristics, preliminary data from the 1985 National Nursing Home Survey. Advance Data From Vital and Health Statistics. No. 131. DHHS Pub. No. (PHS) 87-1250. Hyattsville, Md., Mar. 27, 1987.

${ }^{4}$ National Center for Health Statistics, A. Sirrocco: Inpatient health facilities as reported from the 1973 MFI Survey. Vital and Health Statistics. Series 14, No. 16. DHEW Pub. No. (HRA) 76-1811. Health Resources Administration. Washington. U.S. Government Printing Office, May 1976.

${ }^{5}$ National Center for Health Statistics: Advance report, final mortality statistics, 1984. Monthly Vital Statistics Report. Vol. 35, No. 6 Supp. 2. DHHS Pub. No. (PHS) 82-1120. Public Health Service. Hyattsville, Md., Sept. 26, 1986.

${ }^{6} \mathrm{C}$. Macken: A profile of functionally impaired elderly persons living in the community. Health Care Financing Review. Vol. 7, No. 4. HCFA Pub. No. 03223. Office of Research and Demonstrations, Health Care Financing Administration. Washington. U.S. Government Printing Office, Summer 1986. dents relied primarily on their own income or family support to pay for the first month in the nursing home, and 40 percent relied primarily on the medicaid program to pay for care. $R_{0}$ dents 75 years of age and over were more likely to use th. own income or family support to pay for care at admission than residents aged 65-74 years were. Residents aged 65-74 years were more likely to use medicaid. Elderly black residents were almost twice as likely as elderly white residents to use medicaid as the primary payment source at admission. Overall, 48 percent of elderly residents relied on some form of public funds (medicaid, medicare, other government assistance, or welfare) to pay for their stay at the time of admission.
${ }^{7}$ Institute of Medicine: Racial Differences in Use of Nursing Hom in Health Care in a Context of Civil Rights. Washington, D.C. National Academy Press, 1981.

${ }^{8} \mathrm{~S}$. Katz and C. A. Akpom: Measure of primary sociobiological functions. Int. J. Health Serv. 6(3):493-508, 1976.

${ }^{9}$ M. Meiners and R. Coffey: Hospital DRGs and the need for longterm care services, an empirical analysis. Health Serv. Res. 20(3):359384, Aug. 1985.

${ }^{10} \mathrm{M}$. Cohen, E. Tell, and S. Wallack: Client-related risk factors of nursing home entry among elderly adults. $J$. Gerontol. 20(6):785-792, Nov. 1986.

${ }^{11}$ R. Kane, R. Matthias, and S. Sampson: The risk of placement in a nursing home after acute hospitalization. Med. Care 21(11):10551061, Nov. 1983.

${ }^{12} \mathrm{~K}$. Davis and C. Schoen: Health and the War on Poverty, A TenYear Appraisal. Washington, D.C. The Brookings Institution, 1978.

${ }^{13}$ U.S. Bureau of the Census: Characteristics of the population below the poverty level, 1982. Current Population Reports. Series P-60, No. 144. Washington. U.S. Government Printing Office, 1984.

${ }^{14}$ National Center for Health Statistics, P. J. McCarthy: Replication, an approach to the analysis of data from complex surveys. Vital and Health Statistics. Series 2, No. 14. PHS Pub. No. 1000. Public Health Service. Washington. U.S. Government Printing Office, Apr. 1966.

${ }^{15}$ National Center for Health Statistics, P. J. McCarthy: Pseudore cation, further evaluation and application of the balanced half-sam technique. Vital and Health Statistics. Series 2, No. 31. DHEW Pub. No. (HSM) 73-1270. Health Services and Mental Health Administration. Washington. U.S. Government Printing Office, Jan. 1969. 


\section{Technical notes}

Because the statistics presented in this report are based on ample, they will differ somewhat from figures that would have been obtained if a complete census had been taken using the same schedules, instructions, and procedures. The standard error is primarily a measure of the variability that occurs by chance because only a sample, rather than the entire universe, is surveyed. The standard error also reflects part of the measurement error, but it does not measure any systematic biases in the data. The chances are 95 out of 100 that an estimate from the sample differs from the value that would be obtained from a complete census by less than twice the standard error.

The standard errors used in this report were approximated using the balanced repeated-replication procedure. This method yields overall variability through observation of variability among random subsamples of the total sample. A description of the development and evaluation of the replication technique for error estimation has been published. ${ }^{14,15}$

NOTE: $A$ list of references follows the text.
Although exact standard error estimates were used in tests of significance, it is impractical to present exact standard error estimates for all statistics used in this report. Thus, a generalized variance function was produced for aggregated resident estimates by fitting the data presented in this report into a curve using the empirically determined relationship between the size of an estimate $X$ and its relative variance (rel var $X$ ). This relationship is expressed as:

$$
\operatorname{rel} \operatorname{var} X=\frac{S_{X}^{2}}{X^{2}}=a+\frac{b}{X}
$$

where $a$ and $b$ are regression estimates determined by an iterative procedure. Preliminary estimates of standard errors for the percents of the estimated number of residents are presented in table I.

The $Z$-test with a 0.05 level of significance was used to test all comparisons mentioned in this report. Not all observed differences were tested, so lack of comment in the text does not mean that the difference was not statistically significant.

Table I. Standard errors of percents for residents

\begin{tabular}{|c|c|c|c|c|c|c|}
\hline \multirow[b]{2}{*}{ Base of percent (residents) } & \multicolumn{6}{|c|}{ Estimated percent } \\
\hline & 1 or 99 & 5 or 95 & 10 or 90 & 20 or 80 & 40 or 60 & 50 \\
\hline & \multicolumn{6}{|c|}{ Standard errors in percentage points } \\
\hline $5,000 \ldots$ & 2.84 & 6.22 & 8.56 & 11.41 & 13.97 & 14.26 \\
\hline 10,000 & 2.01 & 4.40 & 6.05 & 8.07 & 9.88 & 10.09 \\
\hline$\ldots \ldots \ldots \ldots$ & 1.16 & 2.54 & 3.49 & 4.66 & 5.71 & 5.82 \\
\hline 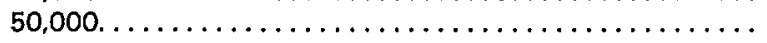 & 0.90 & 1.97 & 2.71 & 3.61 & 4.42 & 4.51 \\
\hline $100,000 \ldots \ldots \ldots \ldots \ldots \ldots \ldots \ldots \ldots \ldots \ldots \ldots$ & 0.63 & 1.39 & 1.91 & 2.55 & 3.12 & 3.19 \\
\hline$\ldots \ldots \ldots \ldots \ldots \ldots \ldots \ldots \ldots \ldots \ldots \ldots$ & 0.45 & 0.98 & 1.35 & 1.80 & 2.21 & 2.26 \\
\hline 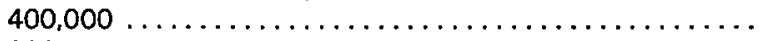 & 0.32 & 0.70 & 0.96 & 1.28 & 1.56 & 1.59 \\
\hline $800,000 \ldots \ldots \ldots \ldots \ldots \ldots \ldots \ldots \ldots \ldots \ldots \ldots \ldots \ldots$ & 0.22 & 0.49 & 0.68 & 0.90 & 1.10 & 1.13 \\
\hline 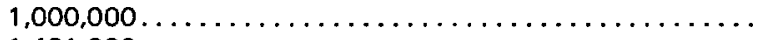 & 0.20 & 0.44 & 0.61 & 0.81 & 0.99 & 1.01 \\
\hline 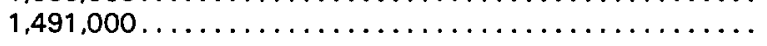 & 0.16 & 0.36 & 0.50 & 0.66 & 0.81 & 0.83 \\
\hline
\end{tabular}

\begin{tabular}{|c|c|}
\hline & Symbols \\
\hline-- & Data not available \\
\hline . & Category not applicable \\
\hline- & Quantity zero \\
\hline 0.0 & $\begin{array}{l}\text { Quantity more than zero but less than } \\
0.05\end{array}$ \\
\hline $\mathbf{Z}$ & $\begin{array}{l}\text { Quantity more than zero but less than } \\
500 \text { where numbers are rounded to } \\
\text { thousands }\end{array}$ \\
\hline$*$ & $\begin{array}{l}\text { Figure does not meet standard of } \\
\text { reliability or precision }\end{array}$ \\
\hline \# & $\begin{array}{l}\text { Figure suppressed to comply with } \\
\text { confidentiality requirements }\end{array}$ \\
\hline
\end{tabular}




\section{Recent Issues of Advance Data From Vital and Health Statistics}

No. 134. Highlights of Drug Utilization in Office Practice: National Ambulatory Medical Care Survey, 1985 (In production)

No. 133. Aging in the Eighties, Functional Limitations of Individuals Age 65 Years and Over (Issued April 30, 1987)

No. 132. Acute Conditions and Retarded Activity During the 198586 Influenza Season (Issued March 27, 1987)
No. 131. Nursing Home Characteristics: Preliminary Data From 1985 National Nursing Home Survey (Issued March 27, 1987)

No. 130. Prevalence of Known Diabetes Among Black Americans (In production)

\section{Suggested citation}

National Center for Health Statistics, E. Hing: Use of nursing homes by the elderly. Preliminary data from the 1985 National Nursing Home Survey. Advance Data From Vital and Health Statistics. No. 135. DHHS Pub. No. (PHS) 87-1250. Public Health Service. Hyattsville, Md., May 14, 1987.

\section{Copyright information}

This report may be reprinted without further permission.

U.S. DEPARTMENT OF HEALTH AND

HUMAN SERVICES

Public Health Service

National Center for Health Statistics

3700 East-West Highway

Hyattsville, Maryland 20782

OFFICIAL BUSINESS

PENALTY FOR PRIVATE USE, $\$ 300$

To receive this publication regularly, contact

the National Center for Health Statistics by

calling 301 436-8500 